\title{
Pandemic, Anthropause, and Healing the Planet
}

Benjamin M. Vallejo Jr.

University of the Philippines Diliman

\section{Abstract}

This paper reflects on the environmental effects of the COVID-19 pandemic, the environmentalist view of the planetary system's holism, and the anthropause. Referenced are religious traditions and the philosophies of three early mid- $20^{\text {th }}$ century marine biologists who are considered founders of the modern environmentalist movement-Edward F. Ricketts, John Steinbeck, and Rachel Carson. Their philosophies on the interconnectedness of the environment provide the inspiration for the Gaia hypothesis which provides the framework for understanding the anthropause, or the hiatus of human domination of the planetary environment resulting from COVID-19 economic lockdowns. Indeed, there might have been a "reset" of the planet's biosphere which is referred to as a "healing of the earth." However, the apparent improvement of the quality of the global environment which validates the predictions of the Gaia hypothesis masks the other unexpected phenomenon of the anthropause such as more economic dislocation resulting in inequality, poverty, and more extractive use of the Earth's resources. From this perspective, the anthropause 
provides human society a pause for reflection. A new global consensus on the nature of human and economic development is needed. This will have to draw from science, the humanities, philosophy, and theological traditions.

\section{Keywords}

sustainable development, natural assets, biodiversity loss, climate change, intraand intergenerational equity 


\section{Introduction}

No doubt, the COVID-19 pandemic has environmental causes. In the face of an existential crisis, it has shed light on the ambiguous relationship between humans and their environment. It is likely, for example, that the zoonosis happened when the ancestral SARS-CoV-2 virus, the pathogen that causes COVID-19, jumped from a bat animal reservoir in central China to an intermediate host, possibly a pangolin, and then to humans (Shereen et al. 92). A large body of evidence suggests that the Sarbecovirus subgroup of coronaviruses evolved from viruses that naturally infect bats, pangolins, and small carnivores in Asia (Morens et al. 556). In 2002, the first documented SARS-CoV-2 emerged in Guangdong Province, China, which killed 889 people and infected 8000 . It was suppressed because it was not very infectious. The intermediate reservoir were civet cats (Wenzel 375). In 2012, the virus that causes Middle East Respiratory Syndrome (MERS) was isolated in Saudi Arabia. The intermediate hosts are dromedary camels, and the primary host remains unknown but is hypothesized to be bats. Like SARS-CoV-2, it is not easily transmitted between humans. Most cases have been in a health care setting where estimated fatality rate is $35 \%$.

Environmental scientists and virologists have been warning of the consequences of habitat destruction in the emergence of new diseases. One of the most documented cases is the Human Immunodeficiency Virus (HIV), the virus that causes AIDS, where zoonosis from apes occurred in the 1920s, at least on three occasions, because of increasing clearing of the African rainforests which expanded the bushmeat trade. HIV spread beyond Africa with the continent's subsequent decolonization (Hillis 1757; Goudsmit 63). For the Sarbecoviruses, the cause is the intensification of agriculture in countries where the forests have been largely cleared but where there is an increased demand for bushmeat (Jones et al. 8400).

With the examples of recent diseases mentioned above, the emergence of infectious diseases is a result of human choices, more specifically economic, and as such can be investigated within an ethical framework as it involves human-nature interaction. This interaction is culturally constructed, and, in some cases, the nature of this interaction is somewhat ambiguous. This 
ambiguity plays a role in our understanding of concepts as important as "healing the earth" and the planetary system's wholeness which is central to current constructions of environmentalism for which we must ask questions on how such ideas came to be.

\section{Constructing the Environment and Human Relations from Philosophical and Religious Ethical Traditions}

First, we must reflect on the ambiguity of the concept of "environment" by asking, "What is the environment?" Environment and nature are part of the observable natural world. Humans exist within that natural world. Greek rationality considered the structures of nature reducible from its inherent complexity, a paradigm of the sciences to the present. The stoic Roman Emperor Marcus Aurelius, however, considered nature as a single entity whose purpose is harmony (Bourdeau 10). The Judaeo-Christian in the first chapters of the Book of Genesis separated man from nature: all nature shall serve man, while man shall serve God, and man was commanded by God to dominate the earth. Thus, Christianity as the offshoot of Judaism is considered as the most anthropocentric of religious traditions (White 1205) even if it had demythologized nature and so became an object of rational understanding ("Laudato Si" 57). However, since the emergence of the ecumenical movement in the $20^{\text {th }}$ century and the Second Vatican Council of the Catholic Church, the nuance of domination has changed to a meaning of stewardship in the Christian churches. The Ecumenical Patriarch of Constantinople, Bartholomew, shares with Pope Francis a theology of integral ecology which recognizes the Earth as a "common home." ("Laudato $\mathrm{Si}$ " 5). This "integral ecology" has been a consensus of the ecumenical movement of the Catholic, Orthodox, Oriental, Anglican, and the Evangelical churches as well as inter-religious dialogue since the Second Vatican Council (Sereti 621). This lack of stewardship is, for the church, an environmental crisis that is a moral problem (John Paul II 2), structural in cause, and rooted in consumption (Benedict XVI 33; Sereti 622).

The Asian philosophical and religious tradition that chimes in with $21^{\text {st }}$ century notions of ecological and environmental holism is Buddhism. 
Buddhist philosophy on the environment is holistic and Buddhist environmental thought is naturalistic as modern ecological science is. However, it does not put a special place for man in nature but is dynamic and cyclical. Unlike philosophies of environmentalism which draws on the natural sciences, it is not materialistic (James 603). Buddhist thinkers maintain that any being, such as a human or a helmeted hornbill is "empty," devoid of value but is emergent from nature (James 606). John J. Holder, a scholar of early Buddhism from St. Norbert College in Wisconsin, USA, and visiting professor of Science, Technology and Society at the University of the Philippines in Diliman, challenges this idea of "devoid of value." Buddhism's idea of value in beings in nature is, according to Holder, with early Buddhist ideas of human continuity with nature, a recognition of "dukkha" or a concern for all beings in the natural world (Holder 116). These emergent properties from nature as observed in detail is central to the "breaking through" and "non-teleological" philosophies of early to mid $-20^{\text {th }}$ century environmentalists such as the American marine biologist, Edward F Ricketts and his friend, the Nobel prizewinning-writer John Steinbeck (Ricketts 103).

Islamic ethical views on the environment are premised on "tawhid" or the majesty, mercy, and all compassion of Allah as the creator of the cosmos and the practice of the Prophet Muhammad, which is to do what is right, forbid what is wrong, and act with moderation at all times (Dien 49; Khalid 709). Muslims do not have the same meaning for nature as the Christians have. The closest Muslim meaning for the Christian idea of nature is the modern Arabic word "bi'a" whose meaning is habitat. As Pope Francis writes in "Laudato Si," nature in Christianity has been demythologized and so is an object for study by science (57). Creation, according to Pope Francis, has a broader meaning than nature and incorporates God's purpose and value of each and every being he created. In this sense, the Muslim idea of creation is that it is a "sign" of Allah's goodness. Muslim environmental ethics is rooted in the Sharia and its application to human needs and the common good.

This concept of interconnections in and wholeness of the planetary environment became the inspiration for philosophical reflection by naturalists of the $19^{\text {th }}$ and marine biologists of the mid $-20^{\text {th }}$ century which eventually 
led to various formulations of interpreting holistic hypotheses in perceiving the planet.

\section{Reflections on the Environment by Naturalists and Marine Biologists}

The $19^{\text {th }}$ century American transcendentalist philosopher and poet Henry David Thoreau (1817-1862) writing in "Walden" (Furtak 3; Thoreau 12) viewed nature as a symbol of spiritual truths in harmony. Thoreau went to the woods deliberately in solitude and in "Walden" challenges his readers to demand more from life, to complete it and flourish in freedom. For Thoreau, freedom is not just liberty from coercion but the freedom to explore and find meaning in nature with the purpose of "living simply." This theme was further developed by Aldo Leopold whose classic essay "The Land Ethic" (1949) makes a moving plea for human restraint in the use of resources and for a greater self-development and worth in deeper reflection of nature (Leopold 5). The marine biologists-Edward F Ricketts (Ricketts 5) and Rachel Carson (Carson, Silent Spring 9; Carson, The Sea around Us 146; Carson and Hubbell 7; Lear 15)-bridge these concepts and philosophical reflections for the latter part of the $20^{\text {th }}$ century when environmental problems and the Cold War arms race were clearly becoming existential crises for human society. Carson's environmental ethics was clearly supported by scientific data in "Silent Spring" (Carson, Silent Spring 17). She criticized an overt anthropocentricism which was ascendant after the Second World War. The evolutionary biologist Julian Huxley in his preface to Carson's book states that the excessive "technological and quantitative" basis of human society is anti-ethical to "ecology in service to man" and that ecology must also ensure the quality of human life for it to flourish. Ecology and human progress must respect human dignity These are themes reiterated by Pope Francis in "Laudato Si" 54 years later. (5) Since "Silent Spring" was about the environmental hazard of pesticides, it intersects with human health and that a holistic environmental ethic based on the interconnectedness of human society and nature is important in human flourishing. 
Ricketts' philosophy of the environment is based on detailed natural observations of species and communities in nature and their interrelationships at each level of biological organization (Sagarin and Crowder 26). These observations were his units for understanding a holistic concept of nature which was possible only with a "non-teleological thinking" philosophy which is the subject of the celebrated Easter Sunday chapter in "The Log from the Sea of Cortez" (Steinbeck and Ricketts 155). In non-teleological thinking, the units for observing nature were essential in building a holistic worldview. In non-teleological thinking, Ricketts wanted to define a concept of nature without preconceived notions or a priori assumptions, an asking of "what" questions rather than of "why," a process that avoids jumping into unwarranted conclusions. In furthering this line of thinking on the road to a holistic understanding, Ricketts called this as "breaking through" (Ricketts 89). "Breaking through" was much influenced by Buddhist philosophy and the idea of compassion for all living things. In turn, his philosophy greatly influenced his friend John Steinbeck who, like Ricketts, studied marine zoology and accompanied him in field expeditions in the Sea of Cortez also known as the Gulf of California.

\section{The Holism of the Gaia Hypothesis}

The philosophical and theological traditions mentioned above form part of the inspiration for and understanding of James Lovelock's Gaia hypothesis. Gaia, the Greek term for Earth goddess, is now a household word worldwide and many people accept the idea that the Earth is a self-regulating entity, similar to that of a living organism. Gaia holism proposes that the Earth is a giant organism where all living and non-living components interact and co-evolve in order to maintain a state of environmental homeostasis ("The Ages of Gaia: A Biography of Our Living Earth” 18; Lovelock and Margulis 8). The concept of an internal environmental condition or homeostasis is taken from medical physiology where WB Cannon first coined the term (Cannon 400). Since the time Lovelock proposed his hypothesis in 1968, Gaia has been the subject of debate and discussion, especially on the teleology and testability of the hypothesis. But can Gaia be seen in Ricketts' 
holistic non-teleological thinking worldview? We must look at the formulations of Lovelock's and Margulis' hypotheses to have an insight on the holistic concept and whether these are testable and can serve as a framework for understanding the environmental effects of COVID-19.

The Gaia hypothesis has five formulations in the order of the "weak and less complex" to the "hard and complex" (Kirchner 224). These formulations are: 1) the Influential, 2) the Co-evolutionary, 3) the Homeostatic, 4) the Teleological, and 5) the Optimizing (Boston 502). The first four formulations are testable, with the first formulation supported by much scientific evidence since it is the simplest of the Gaia hypothesis formulations. This formulation states that at all spatial scales, the biosphere affects the geophysiological environment of the planet (Selley 432). The Co-evolutionary formulation in Darwinian natural selection provides a feedback process in the geophysiological environment. The Teleological formulation is both confirmed and refuted by the Daisyworld computer simulation where, in a hypothetical planet, the populations of black and white flowers result in an equilibrium of constant conditions suitable for life (Lenton and Lovelock 292; Watson and Lovelock 286). Finally, the Optimizing formulation is for a complex system in which the biosphere can regulate itself, resulting in emergent phenomena which may not be predictable. This formulation might not be testable under Karl Popper's falsification criteria (Popper 34).

Since 1974 when the hypothesis was first presented, it has been the subject of debate on whether it was testable and was truly a scientific hypothesis. Computer simulations like Daisyworld have been used to test the hypothesis and its predictions (Watson and Lovelock 294). Extrapolation of predictions to the real earth was at best tenuous as Watson and Lovelock warned in 1983 and advised readers to consider it as a parable. A 2003 reexamination of the model by quantification of ecological, planetary, and evolutionary factors led Lenton and Lovelock to conclude that the model is robust but still must be considered a parable (Lenton and Lovelock 303). The feedback mechanism can only be tested with a stoppage of any of the biological and planetary processes which is unlikely in nature or by the stoppage of the economic 
processes of the human component of the Earth environment. In 2020, an economically disarming virus essentially did that to the anthroposphere.

\section{The Anthropause, Covid-19, and the Healing of the Earth}

SARS-CoV-2 is a remarkable virus. It is the first virus to have resulted in an existential threat to the anthroposphere. In recent history, perhaps it is only HIV that may have been close to being an existential threat to certain sectors of global human society. HIV is called the "most disarming virus" (Goudsmit 1) not only as it attacks the human immune system and disarms it giving rise to AIDS, but it also threatens the economic viability of many countries. To this day, there is no vaccine for HIV although anti-retroviral treatments may guarantee a near normal lifespan for infected people. SARS-CoV-2 and the disease it causes, COVID-19, may be considered as similar. It threatens the economy of the anthroposphere by stalling economic activity in quarantine lockdowns in what is now called as the "anthropause" (Rutz et al. 1156). The anthropause has resulted in changes in human economic and social behavior with shifts in consumption, logistics of supply, food procurement, mobility, education, and knowledge generation. These shifts were a direct result of COVID-19 avoidance behaviors (Buck and Weinstein 2) which were unexpected and emergent.

The first noticeable effect of the anthropause which was observable within a month of the declaration of the global health emergency, was an improvement in air quality with drastic reductions in particulates and nitrogenous emissions worldwide (Kerimray et al.3 ; Li et al.4 ; Rodríguez-Urrego and Rodríguez-Urrego 4; Wang and Su 6). It is estimated that in 2020, 6.4\% of greenhouse gas emissions were cut from predicted rates because of the shutdown of the global economy (Tollefson 158). These improvement effects were throughout the anthroposphere, from reduction of environmental noise, less solid waste deposition on shorelines, less solid waste generation, restoration of beach environments (Soto et al. 8) and even the return of biodiversity to periurban areas such as fish, seaweeds, and seabirds returning to Venice's canals (Rutz et al 1156; "Nature Is Taking Back Venice") and mammalian carnivores returning to the urban parks of Tel Aviv (Stokstad 
893). These massive improvements in environment are at the cost of human social and economic development such as fishery stocks increasing with the economic lockdown of fishing fleets (Stokes et al. 893). Recent contextual assessment of the human and environment nexus suggests that the perceived and measurable improvements in the environment have positive, negative, and neutral effects on human society and the environment. An example is the dramatic increase in medical solid waste because of the pandemic (Sarkar et al. 3) and larger opportunities for biological invasion and killing of predators considered harmful by human communities (Manenti et al. 7). The effects are only now being identified and the interconnections of these effects will be a subject for future research in Earth systems science also known as Gaian sciences. These sciences will try to answer Julian Huxley's question in 1961: "How then can the balance be achieved?"

The Gaian sciences will have to provide insight and understanding of the various nexuses of the human and environment relationships. COVID-19 will have its worse environment and human society nexus outcomes in underdeveloped countries with the global economy expected to contract by $5.2 \%$ in 2020 ("The Global Economic Outlook During the COVID-19 Pandemic"). Underdeveloped countries also have less investment in health care and public health systems (Singh and Misra 1625). With economic dislocation, biodiversity, and ecological economists predict even more unregulated extractive resource use (Forti et al. 3492) which is an emergent consequence of the anthropause.

The anthropause now describes the global hiatus of human domination of the planet (Lawton 21). Before January 1, 2020, the anthropause was an abstraction and a thought experiment of radical environmentalists who did not just theorize a reduction in consumption while ensuring human development goals beyond the classical economic metric of GDP. For them, the anthropause was a new social and environmental order (Jasanoff 341). The anthropause happened not by a social or revolutionary movement, but by a chance event within the parameters of Darwinian evolutionary ecology with the natural release of a coronavirus. The anthropause provides a unique opportunity for scientific research on the "reset" of the global environment 
but this comes with much human suffering and economic dislocation which is expected to continue in the post-COVID-19 era. The consensus is that the anthropause will be temporary and the $6.7 \%$ cut in greenhouse gas emissions in 2020 is still less than the $7.6 \%$ per year estimated to cap global temperature increase within $1.5^{\circ} \mathrm{C}$.

\section{Making Sense of the Anthropause or Anthropauses}

What does it mean to pause? The experience of most of us is like pausing a YouTube video or film at mid-track. Pausing will include reassessment and the time at which it is done involves uncertainty. Pauses also are opportunities to consider before and after scenarios. A pause is disruptive by its very nature (Searle et al. 70) and destabilizing. The 2020 anthropause resulted in perceivable and measurable improvements in environmental quality which led many people in social media to believe that the Earth healed and is consistent with at least the first formulation of the Gaia hypothesis. But if we look at the anthropause with a holistic view in the philosophies of the marine biologists Ricketts, Steinbeck, and Carson, the anthropause with its "what" questions gives rise to emergent phenomenon-unexpected and complex-that we need to understand. Carson's environmental philosophy, which inspired the modern environmental movement, allows us to reflect on the limits of anthropocentrism for the common good which is much echoed by Pope Francis in "Laudato Si," the encyclical letters of the Ecumenical Patriarch Bartholomew, on integral ecology, the Dalai Lama's universal concern for the environment (Dalai Lama 79), and the Islamic environmental ethics. Pope Francis cautions on idolizing the technical in modern anthropocentrism over human relationships (Deane-Drummond 398), a point argued by Julian Huxley in his preface to "Silent Spring." This implies that environmental decisions must be a global social consensus for the common good ("Fratelli Tutti" 66).

It can be argued that the 2020 anthropause was not the first one. It could be the first one at a global scale but other anthropauses have happened and they were all the result of human choices. Some were caused by disasters such as the Chernobyl and the Fukushima nuclear meltdowns. Some were 
political disasters such as the Korean Demilitarized Zone or World War II. The 1929 global Great Depression is an anthropause which resulted in a -0.4 GT decrease in GHG emissions. Others were due to a pandemic disease such as the medieval Black Death, Smallpox because of the European colonization of the Americas, the 1918 Spanish Flu, and the current COVID-19 pandemic; and among all these, it is the COVID-19 pandemic which is of the greatest scale.

Our understanding of the current anthropause is framed in the hyperconnectivity and hypermobility of global society and economies. This is where human society has been most disrupted; this is where the Gaia theory becomes relevant as it is framed as connections in a single planetary environment. In a Gaian framework, hyperconnectivity and hypermobility can be reduced to a single environmental economic metric-the global measure of Greenhouse gas (GHG) emissions. The current pandemic has resulted in a -9.8 GT decrease in GHG emissions twice than the -0.8 GT decrease estimated because of World War II and four times the decrease caused by the 1929 Great Depression (Liu et al. 2). The consequences of the past disruptions were not imagined then as societies coming out from the war and economic depression were able to recover with economic assistance from the international community. The 2020 anthropause, however, places more uncertainty in predicting the socio-economic outcomes than in similar crises in the past. Whether economic assistance can still be provided by the global North to the global South to ensure an equitable socio-economic regime is placed into question.

Ricketts' non-teleological thinking philosophy was framed in natural history and in the context of World War II. Can this be a way to reflect on the pandemic anthropause? Will it allow us to understand the uncertainty associated with it? Non-teleological thinking is further elaborated by Ricketts' friend John Steinbeck as “is” thinking (Rumsby). While teleology will allow us to consider cause and effects, Ricketts and Steinbeck's philosophy recognizes the methodological limitations of finding causes and effects, especially in situations of uncertainty. Non-teleological thinking allows for a wider world of evidence to inform our perception of a phenomenon, such 
as the planetary healing. It anticipates the postnormal science paradigm of Funtowicz and Ravetzs by 60 years (Funtowicz and Ravetz 750).

In an age of anthropauses, will this allow us to make sense of what kind of healing the planet requires? Nobel laureate John Steinbeck's social realist novels were much marine ecological in ethos may provide an avenue for exploring this question of healing through interconnections and emergences of phenomena. Steinbeck's novels were framed in what he called as the Argument of Phalanx (1933). In this argument, Steinbeck characterizes humans as part of a group much like what a cell is to the whole organism, or what a single starfish is to the whole marine ecosystem. A single unit in this system may have a teleology but the whole group of which the unit is a member will have an emergent purpose which the unit never expected. This theory permeates Steinbeck's fiction of the 1930s and his earlier stories in the collection entitled "Long Valley." An example is the story "The Vigilante" (1936) which is about a lynching, takes the "pause" of a witness in which he notes that the lynched was dead, and asks what the purpose of the lynching was and its consequent yet emergent feeling of desolation. The Argument of Phalanx is sociobiological in Steinbeck's framing as reflected in the Log from the Sea of Cortez where he likens the behavior of a school of fish to human society whose only emergent purpose is the Darwinian diktat of survival. But even if it is sociobiological, his later novels such as In Dubious Battle, Tortilla Flat, and Cannery Row, uses a phalanx framework which is tempered with the role of key actors who reflect on their moral judgment premised on freedom of choice and self-determination in a non-teleological sense. And that moral judgement of a human society will exist in human community and solidarity. The healing of the planet will happen through human solidarity. This is Steinbeck's faith in humanity so much trivialized by his literary critics.

Thus, in his 1962 Nobel Prize banquet speech, Steinbeck hoped for the perfectibility of man even with his Godlike power to destroy the world and all living things. Providing redemption and hope for this despite human failings is the vocation of the writer. Perhaps this redemption is in literature with Steinbeck's "Word is Man and with Man” an allusion to the opening verses 
of the Gospel of Saint John. This "Word" is the consensus of where human society is headed. Will this consensus require a redefinition of economic and human development which places a limit on GDP growth and which could be due to an anthropause or repeated anthropauses (Daly 82). Whatever the consensus about what the global human community will be, this has to be inclusive, encompassing the setting of priorities that guarantee long term economic and environmental sustainability (Gibbs 92). Global society will require new economic incentives based on a complex system understanding of the planet with the urgency of pressing global environmental and humanitarian problems expected in the first half of the $21^{\text {st }}$ century. The COVID-19 pandemic is the first global environmental and health nexus crisis of the $21^{\text {st }}$ century and the anthropause provides a benchmark for reflection of a global sustainable future or a future of collapse (Musser 46). In 2005, when Scientific American published a collection of essays titled Crossroads for Planet Earth, the anthropause was never foreseen by environment and society scholars. It was possible in theory with SARS-CoV-2 in 2002, but with science and technology, we were confident in preventing a global pandemic. The global economy did not shut down in 2002. But in a very related but even more economically disarming virus called SARS CoV-2, the global economy went into a hiatus.

Now, we may need the "breaking through" of the marine scientist-philosophers like Ricketts, Steinbeck, and Carson. Redemption is in the mystical and transcendent realization that man is related to the whole thing, to all of reality, as the plankton is to the universe or the tidepool to the stars. This is nothing new-the idea of human community and communion. Such has been known throughout human history by the scientists, holy people, prophets, and saints alike (Steinbeck and Ricketts 257). 


\section{Works Cited}

Benedict XVI. "Caritas in Veritate." Libreria Editrice Vaticana, 2009.

Boston, P. J. "Gaia Hypothesis." Encyclopedia of Ecology, edited by Sven Erik Jørgensen and Brian D. Fath, Academic Press, 2008, pp. 1727-31, doi:10.1016/ B978-008045405-4.00735-7.

Bourdeau, Ph. "The Man-nature Relationship and Environmental Ethics." Journal of Environmental Radioactivity, vol. 72, no. 1, Jan. 2004, pp. 9-15, doi:10.1016/ S0265-931X(03)00180-2.

Buck, Julia C., and Sara B. Weinstein. "The Ecological Consequences of a Pandemic." Biology Letters, vol. 16, no. 11, 2020, p. 20200641, The Royal Society.

Cannon, Walter B. “Organization for Physiological Homeostasis." Physiological Reviews, vol. 9, no. 3, 1929, pp. 399-431.

Carson, Rachel. Silent Spring. Houghton Mifflin Harcourt, 2002.

---. The Sea Around Us. Oxford UP, USA, 2003.

Carson, Rachel, and Sue Hubbell. The Edge of the Sea. Houghton Mifflin Harcourt, 1998.

Dalai Lama [Tenzin Gyatso]. "Universal Responsibility and the Environment." My Tibet, Text by His Holiness the Fourteenth Dalai Lama of Tibet, U of California P, 2020, pp. 79-87.

Daly, Herman E. "Economics in a Full World." Scientific American, vol. 293, no. 3, 2005, pp. 100-107, JSTOR.

Deane-Drummond, Celia. "Laudato Si' and the Natural Sciences: An Assessment of Possibilities and Limits." Theological Studies, vol. 77, no. 2, May 2016, pp. 392-415, , doi:10.1177/0040563916635118.

Dien, Mawil Izzi. "Islam and the Environment: Theory and Practice.” Journal of Beliefs \& Values, vol. 18, no. 1, Apr. 1997, pp. 47-57, doi:10.1080/1361767970180106.

Forti, Lucas R., et al. "Ecological Inheritance for a Post COVID-19 World." Biodiversity and Conservation, vol. 29, no. 11, Oct. 2020, pp. 3491-94, doi:10.1007/ s10531-020-02036-z.

Francis. Fratelli Tutti: Encyclical on Fraternity and Social Friendship. Orbis Books, 2020.

---. "Laudato Si.” Vatican Press, May, vol. 24, 2015, p.w2

Funtowicz, Silvio O., and Jerome R. Ravetz. "Science for the post-normal age.” Futures 25, no. 7 (1993): 739-755. 
Furtak, Rick Anthony. Henry David Thoreau. June 2005. plato.stanford.edu, plato.stanford.edu/entries/thoreau/?utm_campaign=TW A\%20Newsletter\%20for\%20 May\%2030\%2C\%202017\&utm_medium=email\&utm_source=Eloqua\&utm_ content=The\%20W riter\%27s\%20Almanac\%20for\%20May\%2030\%2C\%20 2017\&elqTrackId=71124a62dc2347299fd423259c173bf8\&elq=f22a038adbfe480eb3e7870122d88a8d\&elqaid=28859\&elqat=1\&elqCampaignId=25404.

Gibbs, W. Wayt. "How Should We Set Priorities?" Scientific American, vol. 293, no. 3, 2005, pp. 108-15, JSTOR.

Goudsmit, Jaap. Viral Sex: The Nature of AIDS. Oxford UP on Demand, 1997.

Hillis, David M. “Origins of HIV.” Science, vol. 288, no. 5472, June 2000, p. 1757, doi:10.1126/science.288.5472.1757.

Holder, John J. "A Suffering (but Not Irreparable) Nature: Environmental Ethics from the Perspective of Early Buddhism." Contemporary Buddhism, vol. 8, no. 2 2007, pp. 113-30,

James, Simon P. "Buddhism and Environmental Ethics." A Companion to Buddhist Philosophy, 2013, pp. 599-612.

Jasanoff, Sheila. "Ours Is the Earth: Science and Human History in the Anthropocene." Journal of the Philosophy of History, vol. 14, no. 3, 2020, pp. 337-58.

John Paul II. "Message of His Holiness Pope John Paul II for the Celebration of the World Day of Peace." The Holy See, 1990.

Jones, Bryony A., et al. "Zoonosis Emergence Linked to Agricultural Intensification and Environmental Change." Proceedings of the National Academy of Sciences, vol. 110, no. 21, May 2013, p. 8399, doi:10.1073/pnas.1208059110.

Kerimray, Aiymgul, et al. "Assessing Air Quality Changes in Large Cities during COVID-19 Lockdowns: The Impacts of Traffic-Free Urban Conditions in Almaty, Kazakhstan." Science of the Total Environment, vol. 730, 2020, p. 139179

Khalid, Fazlun. "Islam and the Environment - Ethics and Practice an Assessment." Religion Compass, vol. 4, no. 11, Nov. 2010, pp. 707-16, doi:10.1111/j.17498171.2010.00249.x.

Kirchner, James W. “The Gaia Hypothesis: Can It Be Tested?” Reviews of Geophysics, vol. 27, no. 2, 1989, pp. 223-35.

Lawton, Graham. "Life in the Anthropause." New Scientist, vol. 247, no. 3292, July 2020, p. 21, doi:10.1016/S0262-4079(20)31284-7.

Lear, Linda. Rachel Carson: Witness for Nature. Macmillan, 1998.

Lenton, Timothy M., and James E. Lovelock. "Daisyworld Revisited: Quantifying Biological Effects on Planetary Self-regulation.” Tellus b, vol. 53, no. 3, 2001, pp. 288-305.

Leopold, Aldo. "The Land Ethic.” The Ecological Design and Planning Reader, edited by Forster O. Ndubisi, Island Press/Center for Resource Economics, 2014, pp. 108-21, doi:10.5822/978-1-61091-491-8_12 
Li, Li, et al. "Air Quality Changes during the COVID-19 Lockdown over the Yangtze River Delta Region: An Insight into the Impact of Human Activity Pattern Changes on Air Pollution Variation." Science of the Total Environment, vol. 732,2020, p. 139282,

Liu, Z., Ciais, P., Deng, Z. et al. Near-real-time monitoring of global $\mathrm{CO}_{2}$ emissions reveals the effects of the COVID-19 pandemic. Nat Commun 11, 5172 (2020). https://doi.org/10.1038/s41467-020-18922-7

Lovelock, James. “Gaia: The Living Earth.” Nature, vol. 426, no. 6968, 2003, pp. 769-70.

---. The Ages of Gaia: A Biography of Our Living Earth. Oxford UP, USA, 2000.

Lovelock, James E., and Lynn Margulis. "Atmospheric Homeostasis by and for the Biosphere: The Gaia Hypothesis.” Tellus, vol. 26, nos. 1-2, 1974, pp. 2-10, Manenti, Raoul, et al. "The Good, the Bad and the Ugly of COVID-19 Lockdown Effects on Wildlife Conservation: Insights from the First European Locked down Country.” Biological Conservation, vol. 249, Sept. 2020, p. 108728, doi:10.1016/j.biocon.2020.108728.

Morens, David M., et al. "The Origin of COVID-19 and Why It Matters." The American Journal of Tropical Medicine and Hygiene, vol. 103, no. 3, Sept. 2020, pp. 955-59, doi:10.4269/ajtmh.20-0849

Musser, George. "The Climax of Humanity." Scientific American, vol. 293, no. 3, 2005, pp. 44-47.

"Nature Is Taking Back Venice': Wildlife Returns to Tourist-Free City." The Guardian, 20 Mar. 2020, www.theguardian.com/environment/2020/mar/20/ nature-is-taking-back-venice-wildlife-returns-to-tourist-free-city, Accessed 03 June 2021

Popper, Karl R. "Science as Falsification." Conjectures and Refutations, vol. 1, no. 1963, pp. 33-39,

Rennie, John (ed) Crossroads for Planet Earth. Scientific American, 2005

Ricketts, Edward Flanders. Breaking through: Essays, Journals, and Travelogues of Edward F. Ricketts. U of California P, 2006.

Rodríguez-Urrego, Daniella, and Leonardo Rodríguez-Urrego. "Air Quality during the COVID-19: PM2. 5 Analysis in the 50 Most Polluted Capital Cities in the World.” Environmental Pollution, 2020, p. 115042.

Rumsby, Jeanette "Steinbeck's Philosophy" Steinbeck in the Schools, San Jose State University https://sits.sjsu.edu/context/philosophical-influences/ 2016.

Rutz, Christian, et al. "COVID-19 Lockdown Allows Researchers to Quantify the Effects of Human Activity on Wildlife.” Nature Ecology \& Evolution, vol. 4, no. 9, 2020, pp. 1156-59.

Sagarin, Raphael D., and Larry B. Crowder. "Breaking through the Crisis in Marine Conservation and Management: Insights from the Philosophies of Ed Ricketts." Conservation Biology, vol. 23, no. 1, 2009, pp. 24-30, Wiley Online Library. 
Sarkar, Priyanka, et al. "Coupled Human-Environment System amid COVID-19 Crisis: A Conceptual Model to Understand the Nexus.” Science of The Total Environment, vol. 753, Jan. 2021, p. 141757, doi:10.1016/j.scitotenv.2020.141757.

Searle, A, Turnbull, J, Lorimer, J. After the anthropause: Lockdown lessons for more-than-human geographies. Geogr J. 2021; 187: 69- 77. https://doi. org/10.1111/geoj.12373

Selley, R.C. "EARTH SYSTEM SCIENCE.” Encyclopedia of Geology, edited by Richard C. Selley et al., 2005, pp. 430-34, doi:10.1016/B0-12-3693969/00120-9.

Sereti, Maria G. "The Contribution of Ecumenical Patriarch Bartholomew to the Configuration of an Ecumenical 'Integral Ecology." The Ecumenical Review, vol. 70, no. 4, 2018, pp. 617-26, doi:10.1111/erev.12388.

Shereen, Muhammad Adnan, et al. "COVID-19 Infection: Origin, Transmission, and Characteristics of Human Coronaviruses." Journal of Advanced Research, vol. 24, July 2020, pp. 91-98, doi:10.1016/j.jare.2020.03.005.

Singh, Awadhesh Kumar, and Anoop Misra. "Impact of COVID-19 and Comorbidities on Health and Economics: Focus on Developing Countries and India." Diabetes \& Metabolic Syndrome: Clinical Research \& Reviews, vol. 14, no. 6, Nov. 2020, pp. 1625-30, doi:10.1016/j.dsx.2020.08.032.

Soto, E. H., et al. "How Does the Beach Ecosystem Change without Tourists during COVID-19 Lockdown?” Biological Conservation, vol. 255, Mar. 2021, p. 108972, doi:10.1016/j.biocon.2021.108972.

Steinbeck, John. The Long Valley. Penguin, 1936

Steinbeck, John, and Edward Flanders Ricketts. Sea of Cortez: A Leisurely Journal of Travel and Research. Viking Press New York, 1941.

Stokes, Gretchen L., et al. "COVID-19 Pandemic Impacts on Global Inland Fisheries." Proceedings of the National Academy of Sciences, vol. 117, no. 47, Nov. 2020, p. 29419, doi:10.1073/pnas.2014016117.

Stokstad, Erik. "Pandemic Lockdown Stirs up Ecological Research." Science, vol. 369, no. 6506, Aug. 2020, p. 893, doi:10.1126/science.369.6506.893.

"The Global Economic Outlook During the COVID-19 Pandemic: A Changed World.” World Bank, www.worldbank.org/en/news/feature/2020/06/08/ the-global-economic-outlook-during-the-covid-19-pandemic-a-changedworld. Accessed 18 Feb. 2021.

Thoreau, Henry David. “Walden. 1854.” Edited by J. Lyndon Shanley. Princeton UP, 1971.

Wang, Qiang, and Min Su. "A Preliminary Assessment of the Impact of COVID-19 on Environment-A Case Study of China.” Science of The Total Environment, vol. 728, Aug. 2020, p. 138915, doi:10.1016/j.scitotenv.2020.138915. 
Watson, Andrew J., and James E. Lovelock. "Biological Homeostasis of the Global Environment: The Parable of Daisyworld." Tellus B: Chemical and Physical Meteorology, vol. 35, no. 4,1983, pp. 284-89.

Wenzel, John. "Origins of SARS-CoV-1 and SARS-CoV-2 Are Often Poorly Explored in Leading Publications.” Cladistics, vol. 36, no. 4, Aug. 2020, pp. 374-79, doi:10.1111/cla.12425

White, Lynn. "The Historical Roots of Our Ecologic Crisis." Science, vol. 155, no. 3767,1967, pp. 1203-07. 